Mathématiques et sciences humaines
Mathematics and social sciences

193 | Printemps 2011

Varia

\title{
Gabriel Tarde et la statistique criminelle
}

Criminal statistics according to Gabriel Tarde

\section{Thierry Martin}

\section{OpenEdition}

Journals

Édition électronique

URL : http://journals.openedition.org/msh/11962

DOI : $10.4000 / \mathrm{msh} .17962$

ISSN : 1950-6821

\section{Éditeur}

Centre d'analyse et de mathématique sociales de l'EHESS

\section{Édition imprimée}

Date de publication : 15 janvier 2011

Pagination : 27-35

ISBN : 09876936

ISSN : 0987-6936

\section{Référence électronique}

Thierry Martin, «Gabriel Tarde et la statistique criminelle », Mathématiques et sciences humaines [En ligne], 193 | Printemps 2011, mis en ligne le 01 juin 2011, consulté le 23 juillet 2020. URL : http:// journals.openedition.org/msh/11962 ; DOI : https://doi.org/10.4000/msh.11962

Ce document a été généré automatiquement le 23 juillet 2020

(C) École des hautes études en sciences sociales 


\title{
Gabriel Tarde et la statistique criminelle
}

\author{
Criminal statistics according to Gabriel Tarde
}

Thierry Martin

\section{RÉSUMÉS}

Gabriel Tarde, le juge de Sarlat, attribue à la statistique une place centrale dans sa sociologie, comme le montrent ses études de statistique criminelle. Il y développe une conception originale et lucide du rôle de la statistique, dans laquelle il voit l'instrument privilégié permettant de décrire, non pas l'état, mais l'évolution des phénomènes sociaux. Le but de cet article est d'évaluer la pertinence et les limites de cette conception dynamique de la statistique, en montrant comment elle est étroitement liée chez Tarde à sa doctrine philosophique et sociologique.

Gabriel Tarde, the judge of Sarlat, attributes to statistics a central place in his sociology, as shown by his studies of criminal statistics. He develops an original and clear notion of the role of statistics which he regards as the prefered instrument that allows us to describe not the state but the evolution of social phenomena. The aim of the article is to estimate the relevance and the limits of this dynamic conception of statistics, by showing how it is closely linked, in Tarde's studies, to his philosophical and sociological doctrine.

\section{INDEX}

Mots-clés : imitation, sociologie, statistique criminelle, Tarde

Keywords : criminal statistics, imitation, sociology, Tarde 
AUTEUR

THIERRY MARTIN

Logiques de l'agir, Université de Franche-Comté, 25000 Besançon, thierry.martin@univ-fcomte.fr 